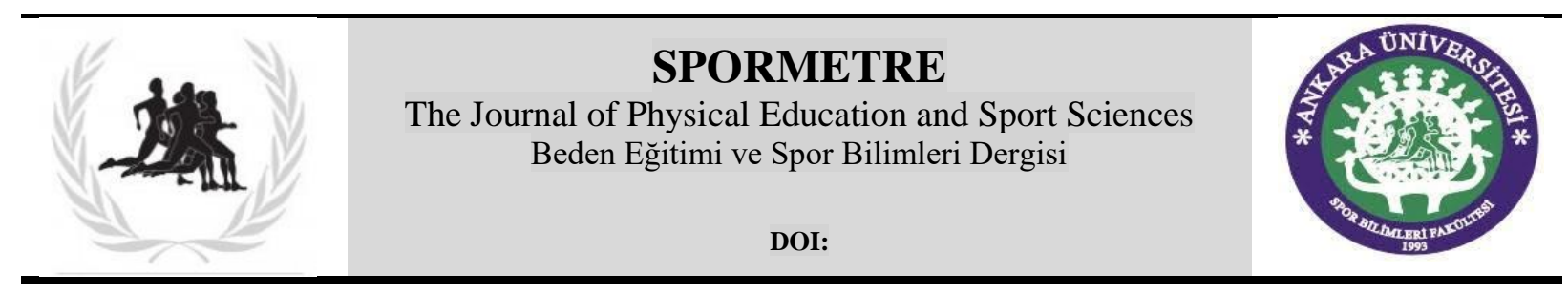

Geliş Tarihi (Received): 27.03.2021

Kabul Tarihi (Accepted): 27.08.2021

Online Yayın Tarihi (Published): 30.09.2021

\title{
FUTBOL TARAFTARLARININ RETORIĞİ: MKE ANKARAGÜCÜ ÖRNEĞİ
}

\author{
Erol İLHAN ${ }^{* 1}$ (D), Utku KABAKCI ${ }^{10}$ \\ ${ }^{1}$ Ankara Hacı Bayram Veli Üniversitesi, İletişim Fakültesi, ANKARA
}

Öz: Retorik, ikna etme tekniklerinin, yollarının kullanılması olarak tanımlanabilir. Futbol taraftarlarının tezahürat ve sloganlarında da ikna etmeye yönelik mesajlar vardır. Bu mesajlar taraftarların hem kendi gruplarına hem de "öteki" olarak gördükleri rakiplerine yönelik olabilir. Çalışmada bu mesajların neler olduğu ve futbol taraftarlarının retoriği incelenmiştir. Örneklem olarak ise MKE Ankaragücü Spor Kulübü tezahürat ve sloganları seçilmiş̧ir. Araştırmada, Aristoteles'in retorik unsurları Ankaragücü taraftarlarının tezahürat ve sloganlarına uygulanarak, hangi duygu, ihtiyaç ve motivasyonlarla harekete geçtikleri yorumlanmaya çalışılmıştır. Taraftarların kendilerine yönelik mesajlarında birlik ve güçlü olma vaadi ön plana çıkarken, rakiplerine yönelik mesajlarında ise meydan okuma ve korkutma amacı dikkat çekmektedir. Futbol taraftarlarının retoriğinin iki önemli vaadi ve unsuru, aidiyet ve "biz" olma ihtiyaçları olarak karşımıza çıkmaktadır.

Anahtar Kelimeler: Retorik, Aristoteles, MKE Ankaragücü, futbol

\section{RHETORIC OF FOOTBALL FANS: THE CASE OF MKE ANKARAGÜCÜ}

\begin{abstract}
Rhetoric can be defined as using the ways and methods of persuasion. Ovations and slogans of football fans also contain persuasive messages. These messages are for themselves and for their rivals who they see as "others". In this study, the messages of the football fans and the oratory behind these messages are examined. Sampling of this study consists of the ovations and slogans of MKE Ankaragücü fans. Rhetorical analysis is applied to these ovations and slogans used by the fans of MKE Ankaragücü. As part of the analysis, Aritoteles' rhetoric elements are checked in order to figure out the ones that are present. Applying rhetorical analysis to the ovations and slogans of the fans formed the basis for interpreting the emotions, needs and motivations that shape their actions. Internal messages of the fans are based on the promise of unity and being strong. When external messages are considered, it is noticed that confrontation and threatening set the purpose. In oratory of football fans, belonging and unity are observed as the two significant factors.
\end{abstract}

Key Words: Rhetoric, Aristoteles, MKE Ankaragücü, football 


\section{GİRIŞ}

"Eski Yunanca'da rhetorike (techne), söz söyleme sanatı, topluluk önünde konuşmak, söylev çekmek anlamında kullanılmıştır. En genel tanımı 'ikna sanatı'dır ve günümüzde 'politik konuşma' olarak bilinmektedir” (Keskin, 2014). Retorik yerine Doğu dillerinde belagat ${ }^{1}$ kelimesi kullanılmaktadır.

Retorik kavramının kökeni Sofistlere kadar gider. Sofistler, polis adı verilen kentlerde dolaşarak talep eden kişilere para karşılığı ders verirlerdi. $\mathrm{Bu}$ dersler güzel ve etkili konuşmayı da kapsamaktadır. Retorik üzerine yapılan çalışmalar Aristoteles'e dayandığı için araştırma, Aristoteles'in klasik retorik yaklaşımı üzerine temellendirilmiştir. Günümüzde retoriğe dair zengin bir literatür dikkati çekmekle birlikte Aristoteles'in retoriğe dair düşünce ve kavramları geçerliliğini sürdürmektedir.

Aristoteles, politika ile iletişim alanları arasında bir bağ kurar. Politika yapmanın yolu ikna tekniklerinden geçer. Politikada meşruluğu kurabilmek için ikna şarttır. $\mathrm{Bu}$ nedenle Aristoteles için retorik son derece önemlidir. Buna karşın Platon, retoriği konuşmacının şahsi çıkarına hizmet eden bir kandırma aracı olarak görmüştür. Antik dönemin bir diğer önemli retorik çalışması ise Cicero'nun “De oratore'si”dir. Bu çalışmada Cicero konuşmacının özellikleri ve görevlerini belirtmiştir (Keskin, 2014).

Retorik kavramına dair olumlu ve olumsuz düşünceler vardır. Kimileri retoriği bir aldatmaca olarak görürken kimileri de retoriğe olumlu anlam ve işlevler yüklemiştir. Bu durum sadece antik dönem için geçerli değildir. Bugün de retoriğe dair farklı görüşler ve tartışmalar mevcuttur. Bir konuşmacının ikna yollarını kullanıyor olması yalan söylediği anlamına mı gelir? Etkili konuşmak ve ikna tekniklerine başvurmak her zaman bir aldatmaca mıdır? İkna tekniklerinden yararlanan bir konuşmacının da hakikati söylüyor ve savunuyor olabileceği göz önünde bulundurulmalıdır. Retoriğin, bilgiye ve hakikate dayalı olabileceği de atlanmamalidir.

Sokrates'in kaleme aldığı en azından bilinen ve günümüze ulaşan bir eseri yoktur. Hocasının savunmasını Platon kaleme almıştır ve Sokrates'in retoriğe dair düşüncelerini bu kitapta görmek mümkündür. Sokrates, daha savunmasının başında şunu söylemiştir: "Bilmiyorum ne hissettiniz ey Atinalılar, beni suçlayanların konuşmalarını dinlediğinizde; ama şunu biliyorum ki ikna edici sözleri bana neredeyse kim olduğumu unutturdu, o kadar etkiliydiler. Ne var ki sözlerinin bir tanesi bile doğru değildi" (Platon, 2010). Burada Sokrates'in etkili konuşmaya dair düşüncelerinin ipuçlarını görmek mümkündür. Sadece bu söz üzerinden Sokrates'in etkili konuşmaya yani retoriğe dair görüşlerinin olumsuz olduğunu söylemenin mümkün olup olmadığı tartışılabilir. Ancak yine de bir fikir vermesi açısından önemlidir.

Sokrates, diyalog ile insanları hakikate ulaştırmaya çalışmıştır. Sokrates için diyalektik iki kişi arasındaki felsefi konuşmalardır. Sokrates diyalog yöntemi ile insanları sanılardan kurtarıp, doğru bilgiye ulaştırır. Platon'un ideal olarak gördüğ̈̈ kent devletinde ise filozof-kral vardır. Hakikate ulaşabilecek olan filozoflardır. Sokrates ise herkesle konuşarak onların karanlıkta

\footnotetext{
${ }^{1} \mathrm{Bu}$ iki kelime tam olarak aynı anlama gelmese de günlük dilde birbirinin yerine kullanılmaktadır. Retorik ve belagat kelimelerinin tam manasıyla birbirlerine denk gelmiyor olmasının nedeni belagat kelimesinin yazının etkili olması anlamının yanında bir de görünenin arkasındaki daha derin bir manaya işaret etmesinden kaynaklanmaktadır. Retorikte ise ileti gizli, örtük olmak durumunda değildir. Retorikte iletinin manevi bir karşılığının olması da gerekmemektedir. Belagat ise daha çok maneviyat ve ruhla ilgilidir.
} 
kalmış bilgilerine ulaşabileceklerine inanır. Sokrates için filozof "bilgiyi seven" kişidir. Platon ise filozofun gerçekleri açıklama ve ülkeyi yönetme görevinin olduğunu söyler (Keskin, 2010).

İnsanlara sorular yönelterek doğruya ulaşmalarını amaçlayan Sokrates için mekânın ya da araçların pek bir önemi yoktur. Önemli olan insanların içlerinde zaten var olduğunu düşündüğü doğru bilgiye onları ulaştırmaktır. Platon, hocası Sokrates'in aksine eğitimde de seçkinci bir tavra sahiptir. Akademinin kurucusu olan Platon için yer ve öğrenci önemlidir. Hakikati kavrayabilecek olan filozoflardır. Bu nedenle ülke yönetiminde ve eğitimde sıradan insanların yeri yoktur.

"Retorik diyalektiğin eşdeşidir" (Aristoteles, 2016:33). Diyalektik ise, "Yunanca dialektike, tartışma sanatı, Latince dialectika, tartışmayı yönetme sanatıdır. Diyalektik, tartışmalı konuların açıklamalar ve karşı açıklamalar (tez ve antitez) aracılığıyla ve sonundaki çıkarımla (sentez) doğru bir şekilde sunulduğu felsefenin ve retoriğin bir yöntemidir” (Keskin, 2014).

Platon diyalektiği bir metot, bir bilgi ve bir bilim olarak felsefe ile özdeş kılmasına rağmen, diyalektiğin kendisi ile bir problem olarak ilgilenmemiştir. Bununla birlikte onun diyalektiği kendi epistemolojisi ve ontolojisi arasındaki bağ olarak uygulaması, bütün felsefe tarihi boyunca diyalektiğin bir metot olarak tanım ve işlevini etkilemiştir. Ancak buna rağmen diyalektiğin bir metot olarak ilkelerini ve işlevini belirleyip tanımlayan Platon değil, Aristoteles olmuştur. Ancak Aristoteles diyalektiğin ilke ve kurallarını belirlerken, bunları kendi tanımına indirgeyerek yaptığı için Platon'un diyalektiğinin ontolojisi geriye çekilerek salt bir uslamlama metot anlayışı öne çıkmaktadır (Delice, 2007).

Diyalektik mantık ile ilişkilidir. Mantık ile aynı anlamda da kullanılmaktadır. Diyalektik, tartışmayı mantık çerçevesinde yönetme anlamına da gelir. Aristoteles'e göre retorik bir sanat, iş ve uğraştır. Retorik, kanıtlarla inandırmaya dayanır. "İnandırma bir tür gösteridir, çünkü bir şeyin gösterilmiş olduğunu düşündüğümüzde tam olarak inanmış oluruz" (Aristoteles, 2016). $\mathrm{Bu}$ nedenle politik söylevciler belge göstererek konuşma yapmayı tercih ederler. "Retorik, belli bir durumda, elde var olan inandırma yollarını kullanma yetisi olarak tanımlanabilir" (Aristoteles, 2016:37). Ancak "Ne retorik ne de diyalektik başlı başına bir konunun bilimsel incelemesi değildir; her ikisi de kanıtlar sağlama yetisidir" (Aristoteles, 2016).

Aristoteles'e göre diyalektik, kanıtlanamayan ve doğruluğu sadece olumsal alanda kendini gösteren alanlar için geçerli bir yöntemdir. Diyalektik ile retorik arasında Aristoteles'in kurduğu ilişkiye göre ilki, ikincisinin bilimsel tartışmaya ilişkin kısmıdır. Kısaca diyalektik, ikna etme sanatı olan retoriğin kanıtlama ve çürütme üzerine yapılan bilimsel tartışma kısmıdır (Altınörs, 2011).

$\mathrm{Bu}$ ön bilgiler rehberliğinde çalışma kapsamında ele aldığımız MKE Ankaragücü Spor Kulübü tezahürat ve sloganlarında da ikna etmeye yönelik çok sayıda mesaj olduğu görülmektedir. $\mathrm{Bu}$ mesajlar taraftarların kendi guruplarına yönelik olabileceği gibi, rakip, öteki ve hatta düşman olarak gördükleri diğer kulüplere yönelik olabilmektedir. Araştırmada bu mesajların hangi başlıklar etrafında toplandığı ve futbol taraftarlarının retorik unsurları incelenmiştir. Aristoteles'in retorik unsurları Ankaragücü taraftarlarının tezahürat ve sloganlarına uyarlanarak, hangi duygu, ihtiyaç ve motivasyonlarla harekete geçtikleri yorumlanmaya çalışılmıştır. 
Çalışmanın kavramsal kısmında klasik dönemin önde gelen düşünürleri, Sokrates, Platon, Aristo ve Cicero'nun görüşlerine yer verilerek retorik anlayışları ortaya konulmaya çalışılmıştır. Çalışma kapsamında tribün liderlerinin de üzerinde birleştiği, halen kullanılan ve güncelliğini koruyan 20 tezahürat belirlenerek analiz yapılmıştır.

\section{PLATON VE RETORÍK}

Çalışmayı temellendirdiğimiz Aristoteles ve retorik anlayışı üzerinde durmadan önce hocası Platon'un retoriğe bakışını kısaca açıklamakta fayda görülmektedir. Platon retoriğe, bir aldatmaca, kandırmaca olarak bakar ve olumsuz bir bakış açısıyla yaklaşır. Platon'un "Gorgias" adlı eserinde Sokrates'in sofistleri retorik konusunda eleştirdiği görülmektedir. Platon'a göre retorik doğruyu ortaya koymaz, tek amacı ikna etmektir. Bunun için de kandırmacaya başvurulur.

Gorgias, derslerine gelecek olanları iyi birer hatip yapacağını ve öğrencilerinin kalabalıklar önünde başarıyla konuşabileceğini söylediğinde Sokrates- "Kalabalık demekle bilgisizler demek istiyorsun herhalde; çünkü, bilgili insanlar önünde, hatip kuşkusuz hekimden daha az ikna edici olacaktır" (Platon, 2017). Sokrates, retoriği dalkavukluk olarak görür. Çünkü ona göre retorikte amaç iyiye, doğruya ulaşmak değil, aptalları kandırmaktır. Sokrates, retoriği akıldan yoksun bulur. Bu yüzden de retoriğin sanat olmadığını söyler (Platon, 2017:30). Sokrates, Kallikles ile olan diyaloğunda da birisiyle konuşurken amacının onu hoşnut etmek olmadığını söyler. Sokrates’in ölçütü iyi olana yaklaşma çabasıdır. Konuştuğu kişinin rahatsız olacağını bilse de iyi olanı aramaya devam eder (Platon, 2017). Sokrates, retoriğin amacının karşı tarafı hoşnut tutarak kandırmak olduğu görüşündedir. Sokrates, Kallikles ile olan diyaloğunda en iyi yolun doğruluk olduğunu ve doğruluk ile örtüşmediğini düşündügü retorik anlayışını terk etmesini öğütler (Platon, 2017).

Platon, retoriği değil, diyalektik düşünceyi ön plana çıkarır. Platon'a göre hakikate giden yol "eros" adını verdiği felsefi bir dürtü ile doğru yöntemi buluşturmaktan geçer. Bu doğru yöntem ise diyalektik düşünmedir. Diyalektik, konuşma yöntemi ve ortak araştırma ile sarsılmaz olan hakikate yaklaşmaya yarayacaktır. Platon, bu yöntem ile hem genelden özele hem de özelden genele doğru bir zihinsel gezi ile hakikate yaklaşllabileceğini söyler (Platon, 2005).

Platon, Aristoteles'in aksine çok net bir şekilde retoriği ve diyalektik düşünmeyi birbirinden ayırır. Platon'a göre diyalektik düşüncede felsefi bir dürtü ve karşılıklılık vardır. Fakat retorikte ise çoğunlukla tek tarafin kendisini dinleyenleri ikna edebilmek yani aldatabilmek için ortaya koyduğu bir çaba söz konusudur. Hakikati kavrayabilmek felsefi bir dürtü, felsefi bir yaklaşım ve bu yaklaşıma uygun olan diyalektik ile mümkündür. Platon, Devlet adlı eserinde, etik ve politik konularda diyalektiği son tahlilde matematikteki kesin sonuçlara ulaşmayı sağlayan bir yöntem olarak ortaya koyar.

Retoriğe getirilen bir diğer eleştiri de kitleleri manipüle etmek için kullanıldığ 1 yönündedir. Platon için retorik, bir sanat, uğraş ya da meslek değildir. Retorik hakikate dayanmaz ve bilgisiz insanları aldatmak için kullanılan bir araçtır. Platon'un "Gorgias" adlı eserinde retoriğe karşı tutumunun çok sert olduğu görülmektedir. Platon'a göre iyi konuşmak ne bireye ne de topluma bir şey kazandırmaz. Retorik, mutluluk ya da doğru bilgi getirmez.

Gorgias retoriğin seslenilen kişileri ikna etmek kadar, münazaradaki muhatabı "mağlup etmek" için de avantajlı bir manivela olduğunu savunur. Gorgias'ın bu savının, hakikati bulmada izlenmesi gereken yol hakkında Sokrates ve Platon'un felsefesi ile tamamen zit 
olduğu açıktır. Sokrates ve Platon için bir tartışmada amaç, rakibi mağlup etmek değildir. Karşı1 görüşlerin çarpışması yöntemiyle gerçeğin ortaya çıkarılmaya çalışılmasıdır. Bu kapsamda amacı galip gelmek olan bir tartışmanın, hakikatin araştırılmasıyla hiçbir bağlantısı yoktur. Gorgias ve Sofistlerin ikna ve etkileme öncelikli söylemi karşısında, bilgiyi ortaya çıkarabilecek bir retorik mümkün görünmektedir. Platon'un bu retorik anlayışı, öğrencisi Aristoteles tarafından daha kapsamlı hale getirilecektir (Altınörs, 2011).

\section{ARISTOTELES VE RETORİK}

Aristoteles'e göre sözün üç inandırma tarzı vardır. Bunlardan ilki konuşmacının karakteri ile ikincisi dinleyenleri duygulandırarak belirli bir ruh haline getirmekle, sonuncusu ise konuşan kişinin kelimelerinin sağladığı tanıtla ya da sözde tanıtla ilgilidir. Sözün bu üç inandırma tarzından da anlaşıldığı gibi konuşmacının; karakteri, duyguları harekete geçirebilme becerisi ve konuya uygun kanıtlar ortaya koyup koyamadığı dinleyiciler üzerinde etkilidir. Eğer dinleyenler konuşmacının iyi ve güvenilir biri olduğunu düşünüyorlarsa söylenenlere inanma ihtimalleri artar. Bununla birlikte konuşmacı kendisini dinleyenleri iyi analiz etmişse onların duygularını, hassasiyetlerini bilir ve bu duyguları harekete geçirebilir. Ayrıca konuşmacının söyledikleri uygun kanıtlara dayanıyor ise daha etkili olacaktır. Demek ki konuşmacı, mantık çerçevesinde düşünebilmeli, insan karakterlerini bilip ona göre davranmalı ve duyguları yönetebilmelidir (Aristoteles, 2016). Bu üç inandırma tarzından birincisi yani karakter doğrudan konuşmacı ile ilgili olup doğuştan gelir. Diğer iki unsur ise zamanla geliştirilebilecek becerilerdir. Konuşmacı performans sergilerken bu üç unsuru en iyi şekilde kullanmalıdır. Konuşmacının performansı bu üç unsuru nasıl kullandığı ya da kullanmadığı üzerinden analiz edilebilir.

Sergilenen performanslar çok önemlidir. Çünkü ortaya konan roller bizi o kişilere dair fikir sahibi yapar. Kişilere dair rol tahminleri insanlarla olan ilişkilere ve gözleme bağlıdır. Rol tahmini ve ikna arasında önemli bir bağ vardır. Bu tahminler genellikle ilk izlenimlere ya da o kişiye dair inandırılan şeylere dayanır. Rol tahminleri de en nihayetinde genellemeler yapılmasına kadar gider. Rol tahmini; grupların, kişilik tiplerinin ve tek tek bireylerin olabilir (Beer, 2001). Tek tek bireylerin değil, grupların ve kişilik tiplerinin rol tahminlerini isabetli yapabilmek, işi ikna olan biri için çok önemlidir. Çünkü hangi durumlarda nasıl davranacaklarını tahmin edebilme ve bu tahmin üzerinden insanları veya grupları yönlendirebilme imkânını sağlar.

Aristoteles için retorik Sokrates'in aksine tek tek şahıslar ile değil, aynı tipten olan insanlarla ilgilidir. Çünkü bireysel durumlar karmaşık ve çok çeşitlidir. Tek tek şahıslar için her zaman ve her durumda geçerli olacak kuralları ortaya koymak pek mümkün değildir. Bu nedenle retorik sanatı şahsi durumlarla ilgili genel bir ifade ortaya koyamaz (Aristoteles, 2016).

Aristoteles, retoriği bir "ikna sanatı" olarak yorumlamıştır. Aristoteles'in ethos, pathos ve logos kavramları ikna sürecinde önemli bir yer tutmaktadır. Ethos, karakter ya da etik olarak, pathos, duygulara dokunabilme, seslenebilme olarak, logos ise belge, mantık olarak ifade edilebilir. Aristoteles bir konuşmacının logos, ethos ve pathos'u kullanabilmesi için; argümantasyon yapabilmesi, adetler ve faziletler hakkında bilgi sahibi olması, söz söylediği kişide çeşitli etkiler ya da şiddetli duygular uyandırma yöntemlerini bilmesi gerektiğini ifade etmektedir (Aristoteles, 2016).

Aristoteles, politika ve iletişimi birbirinden ayırmaz. Politikacı, insanları ikna edebilmelidir. Retorik burada devreye girer. İkna teknikleri kullanılarak meşruiyet kazanılır. Aristoteles, 
politikada ikna üzerinde durduğu yani iletişimin altını çizdiği için politik iletişimin önünü açan isim olarak adlandırılabilir.

"Retorik, konuşmaları dinleyen üç sınıf dinleyiciye göre üç bölüme ayrılır. Çünkü konuşma isteminin üç ögesinden-konuşmacı, konu ve seslenilen kişi- konuşmanın amacını ve hedefini belirleyen bu sonuncusu, yani dinleyicidir. Dinleyici ya geçmiş ya da geleceğe ait şeyler üzerinde bir karar verme durumunda olan bir yargıç, ya da bir gözlemci olmalıdır" (Aristoteles, 2016).

Üç söylev türü vardır. Bunlar; politik, adli, törensel gösteri söylevleridir. Politik söylev, dinleyenleri bir şeyi yapmaya ya da yapmamaya yönlendirir. Politik söylevciler de dinleyicileri ya bir şeye yönlendirir ya da bir şeyden uzaklaştırır. Adli söylev, mahkemelerde bir kişiyi savunmak ya da suçlamak ile ilgilidir. Törensel gösteri söylevi ise birini övmek ya da kötülemekle ilgilidir. Bu üç farklı söylev türü üç farklı zamana da işaret eder. Politik söylev gelecek ile ilgilidir. Gelecekte yapılacak şeyler ile ilgilidir. Adli söylev geçmişle ilgilidir. Geçmişte yapılmış bir şey dolayısıyla kişi ya savunulur ya da suçlanır. Törensel söylev ise şimdiki zamanla ilgilidir. Geçmişe ya da geleceğe dair şeyler söylense de o an için kişi ya övülür ya da kötülenir (Aristoteles, 2016).

Politik söylevde konuşmacının ana konu sayısı beş tanedir. Bunlar; yollar ve araçlar, savaş ve barış, ulusal savunma, dışalım ve dışsatım ile yasalardır. Politik söylevcinin bu konulara dair bilgili olması gerekmektedir. Politik söylevcinin bu konularda sadece kendi ülkesini değil aynı zamanda diğer ülkeleri de biliyor olması şarttır (Aristoteles, 2016).

Dinleyicileri ikna etmek isteyen bir hatip belli başlı konulara dair bilgi ve fikir sahibi olmak durumundadır. Bilgi ve fikir sahibi olmakla birlikte politik söylevci diğer yerlerdeki iyi ve kötü örnekleri de bilmeli ve kıyas yapabilmelidir. Politik söylevde mesaj politik bir amaç taşır. Hatip amacına ulaşmak istiyorsa dinleyenlerle doğru bir iletişim kurmak zorundadır. Politik söylevde dinleyenleri ikna etmenin yolu duygulara seslenebilmekten, konuşmacının iyi imajından ve bilgili olmasından geçer. Konuşmacı bilgili olmak ya da öyle görünmek durumundadır. Retorik bilgiye dayanmazsa etkili olsa bile bu kısa süreli olacaktır. Bilgiye dayanmayan konuşmayı çürütmek çok daha kolay olacaktır. Bu bakımdan retoriğin bilgiye ve kanıta dayanması ikna yolunda konuşmacıya büyük avantaj sağlayacaktır.

Politik söylevcinin insanlara seslenirken, amacının onların mutluluğu olduğunu göstermesi gerekir. Çünkü insanların yöneldiği amaç mutluluktur. Mutluluk, insanların ulaşmak istedikleri ya da uzak durmak istedikleri şeylerle ilgilidir. "Mutluluğu erdemle birleşmiş refah olarak tanımlayabiliriz ya da yaşam bağımsızlı̆̆ı olarak ya da en çok hazdan güvenli yararlanma olarak; ya da insanın malını mülkünü ve bedenini koruma ve onları kullanma gücüyle birlikte varlığın ve bedenin iyi bir durumda olması olarak" tanımlanabilir. Mutluluğun bu tanımından unsurları da çıkartılmaktadır. Bu unsurlardan bazıları iç, bazıları ise dış unsurlardır. Politik söylevci mutluluğun iç ve diş unsurlarını bilmeli ve kendisini dinleyenlere mutluluğu vaat etmelidir (Aristoteles, 2016).

Politik söylevci, konuşmasında insanların yararından söz etmelidir. İyi olan şey insanlar için yararlıdır. Bu nedenle dinleyicilerin dikkatini çekebilmek için iyi olan şeylerden bahsetmek gerekir. İyi olan ise; mutluluk, adalet, cesaret, ölçülülük, yüce gönüllülük, görkem, güzellik, sağlık, dostluk, zevk, yaşam, zenginlik, onur, ün, vb. şeylerdir. Ayrıca düşmanın zararına olan şey de iyi olarak kabul edilir (Aristoteles, 2016). Politik söylevci, hangi koşularda neyin iyi olduğunu, neyin daha iyi olduğunu bilmek durumundadır. 
Törensel gösteri söylevinde önemli olan, erdem-kusur ve iyi-kötüdür. Konuşmac1 bu kavramları kullanır. Çünkü bu kavramlar övme ve ayıplama için kullanılırlar. Törensel gösteri söylevinde de şimdiki zamanda bir kişi ya da şey, iyi-kötü ya da erdem-kusur kavramları ile ya övülür ya da eleştirilir (Aristoteles, 2016).

Törensel gösteride konuşmacının dinleyicilerin değerlerini iyi bilmesi gerekir. Dinleyenler için neyin iyi neyin kötü olduğu bilinmelidir. Hatip, dinleyicilerini değerleri üzerinden yakalar. İyi ve kötü olan üzerinden dinleyenleri ikna etmeye çalışır. Bu nedenle konuşmacı dinleyicilerinin değer yargılarını ve yaşama karşı duruşlarını bilmek durumundadır. Neyin iyi neyin kötü olarak kabul edildiğinin bilinmesi önemlidir. Çünkü ülkeden ülkeye hatta gruptan gruba değişiklik gösterebilir. Konuşmacının işini kolaylaştıracak olan yerleşmiş değerler ile çelişen ve çakışan düşüncelerden uzak durmasıdır. Bunun yerine dinleyici grubunun değer yargılarıyla örtüşen bir dil seçilmelidir. Aksi durumda dinleyenleri ikna etmek çok daha zor olacaktır.

Adli söylevde ise suçlama ya da savunma esastır. Bu söylev türünde konuşmacı, insanların hangi koşullarda suç işleyebileceğini, bu suçu hangi nedenlerle işlediğini, haklı ve haksız olunan durumları ve kötülükten söz edebilmek için şart olan unsurları iyi bilmesi gereklidir. Çünkü suçlama da savunma da bunlar üzerinden yapılır (Aristoteles, 2016). Adli söylevlerde sıklıkla kullanılan beş inandırma yolu mevcuttur. Bunlar; yasalar, tanıklar, işkenceler, yeminler ve anlaşmalardır. Bu yollar konuşmacı tarafından suçlama ve savunmada, inandırma ve caydırmada kullanılırlar (Aristoteles, 2016).

Özellikle politik söylevde aynı zamanda adli söylevde de konuşmacı dinleyenlerde karakterinin doğru olarak, iyi olarak görülmesini sağlamalıdır. Böylece konuşmacının inandırıcılığı artacaktır. Konuşmacının kullandığı belge ve dayanaklardan ayrı olarak söylediklerinin doğruluğuna inandıran üç şey vardır. Bunlar; sağduyu, ahlaki karakter ve iyi niyettir (Aristoteles, 2016).

Konuşmacı duyguları özellikle de öfke duygusunu harekete geçirme konusunda becerikli olmalıdır. Öfke düşmana yöneltilir. Öfke beraberinde belirli bir zevk de getirir. Çünkü öç alma isteği kişiyi diri tutar. Öç alma arzusu başlı başına bir motivasyon kaynağı olur (Aristoteles, 2016). Öfke insanları bir arada tutar. Öfkeden doğan bir kardeşlik ve dayanışma ruhu konuşmacı tarafindan hem kitleyi bir arada tutar hem de düşmana karşı eyleme geçirir. Kitleyi sadece düşmana karşı öfkelendirmek yeterli değildir. Öç alınacağı inancının da yerleştirilmesi gerekmektedir. Aksi durumda insanlar eyleme geçmeyecektir.

Konuşmacının etkili bir şekilde kullanması gereken bir diğer duygu da korkudur. Konuşmacı, dinleyenleri korkutması gerektiğinde tehlikenin yakınlarında olduğunu onlara hissettirmelidir. Böyle bir tehlikenin daha önce kendileri gibi olan insanların başına geldiğinden söz etmelidir. Dinleyiciler korktuklarında güven duygusuna ihtiyaç duyacaklardır. Güvendiklerinin yanlarında, korktuklarının ise uzaklarında olmasını isteyeceklerdir. $\mathrm{Bu}$ durum oluşturulduğunda hatip dinleyenlerde güven duygusu oluşturmalıdır (Aristoteles, 2016).

"Korku insanı teşvik eden güçlü bir psikolojik kuvvet olabilir, bütün enerji ve düşüncelerimizi bu tehdidi kaldırmaya kanalize ederiz ve böylelikle başka bir şey düşünmemiz imkansızlaşır" (Pratkanis ve Aranson, 2008). İnsanları ikna edebilmek duygulara dokunmakla ilgilidir. Duygularına seslenilebilen insan kolaylıkla ikna edilebilir. Korku da çok kuvvetli bir duygudur ve bu nedenle ikna sürecinde kullanılabilir. Korkulan veya korkutulan şey gerçek olabilir de olmayabilir de, önemli olan insanları duygularından yakalayabilmektir. 
“Öteki” üzerinden korku üretmek ve bu korkuyu yönetebilmek mümkündür. “Öteki” bütün kötülüklerin nedeni olarak gösterilir. "Öteki” olana duyulan öfke de "biz" duygusunu kuvvetlendirir. Öfke ve korku duygularına dokunabilen bir konuşmacı çok daha etkili olacaktır. İkna etmekte duygulara dokunabilmek çok çok önemlidir. Yönlendirmede akıldan çok duygulara dokunabilmenin daha etkili olduğunu söylemek mümkündür. Tek tek bireyler için olmasa da kitleyi yönlendirebilmek için duyguları doğru yönlendirmek gerekmektedir. Bu nedenle hatipler sık sık duygular üzerinden ikna stratejilerini kurarlar.

Bütün konuşmacılar kişisel özelliklerinden başka yani kendilerine özgü kanıtlama yollarından başka dört temel unsuru kullanırlar. Bunlar; mümkün olan ve mümkün olmayan, geçmiş olgular, gelecek olgular ve göreceliliktir. Konuşmacı bir şeyi olduğundan büyük ya da küçük göstermeye çalışır, bir şeyin mümkün olduğuna ya da olmadığına ikna etmeye çalışır, geçmiş ya da gelecek olgulara başvurur (Aristoteles, 2016). Bu tekniklerin de ötesinde konuşmacı mesajına başka insanları da ortak etmelidir. Eğer konuşmacı başka insanları da hayallerine ortak edebilirse başarılı olur. Doğrudan diyalog grubundan olmasa da ulaşılan her insan amaca gidilen yolda birer kazanımdır. Çünkü amaca ulaşılacak yolun seçiminde başkalarından duyulanlar da etkilidir. Konuşmacı bu nedenle karakterini ve mesajını mümkün olduğunca nasıl görünmesini istiyorsa öyle göstermeye çalışmalıdır. Bu yolda ulaşılan her insan her grup kıymetli olacaktır.

Bütün hitabet türlerinin iki ortak biçimi vardır. Bunlar, örnek ve örtük tasımdır. Örneklemede tümevarım kullanılır ve bundan yararlanılır. Örneklemede kanıtın iki türü vardır. Birincisi hakiki geçmiş olgulara dayanması, ikincisi ise konuşmacının icat ettiği örneklerdir. Konuşmacının icat ettiği örneklerin de iki türü vardır. Birincisi betimleyici koşutluk, ikincisi ise hayvan masallarıdır. Eğer örnekler başta veriliyorsa çok sayıda örneğin kullanılmasında yarar görülür. Ancak sonda örnek verilecekse tek bir örnek yeterli olacaktır (Aristoteles, 2016).

Maksim, genel ifadeler olarak tanımlanabilir. Dinleyiciler özel bağlamda inandıkları şeylerin genel bağlamda dile getirilmesinden hoşnut olurlar. Yani şahsi deneyimleri her zaman her koşulda geçerliymiş gibi genel ifadeler ile kendilerine söylendiğinde bu etkili olacaktır. Konuşmacı, dinleyicilerin şahsi görüşlerini bilir ya da tahmin edebilirse bir avantaj sağlar. Dinleyenlerin bir meseleye dair görüşlerini genel ifadeler ile anlatarak onları çekmiş olur (Aristoteles, 2016).

Örtük tasımın bir türü olumlu ya da olumsuz bir önermeyi tanıtlar, diğer türü ise çürütücü örtük tasımdır. Konuşmacının yararlanabileceği farklı doğrulama ya da çürütme teknikleri vardır. İyi bir hatip bu iki biçimi ve maksim kullanımını başarılı bir şekilde yapandır. Konuşmacı bu teknikleri kullanmada mahir olduğu ölçüde kendisini dinleyenleri etkisi altına alacaktır. $\mathrm{Bu}$ teknikler öğrenilip geliştirilebilecek tekniklerdir. Örtük tasımların dayandırılabileceği dört durum vardır. Bunlar; örnekler, olasılıklar, sıradan belirtiler ve şaşmaz belirtilerdir. Örneğe dayalı örtük tasımlarda, bir ya da birden fazla tümevarımla genel bir önermeye ulaşılır. Daha sonra ise tümdengelimle özel bir çıkarıma ulaşılır. Olasılıklara dayandırılan örtük tasımlarda, genellikle hakikat olan ya da gerçek olması gereken şeyden hareket edilir. Sıradan belirtilere dayandırılan örtük tasımlarda ise gerçek ya da değil herhangi bir tikel veya evrensel önermeden hareket edilir. Şaşmaz belirtilere dayandırılan örtük tasımlarda ise tartışılamaz ve değiştirilemez olan bir şey üzerinden yola çıkılır (Aristoteles, 2016). 
Bir konuşma sırasında üç önemli nokta vardır. Birincisi, inandırma yollarıdır. İkincisi, dil ya da biçemdir. Üçüncüsü ise konuşmanın bölümlerinin uygun bir şekilde düzenlenmesidir. İnandırma yolları üç tanedir. 1. Konuşmacının karakterinin doğru, iyi yansıtılması. 2. Dinleyenlerin duygularının harekete geçirilmesi. 3. Konuşmanın içeriğine dair uygun kanıtların ortaya konmasıdır (Aristoteles, 2016). Tüm söylev türleri için bu üç nokta çok önemlidir. Bu üç noktada başarıyı yakalayan hatip amacına kuvvetle muhtemel ulaşacaktır.

Ne söyleneceği kadar, nasıl söyleneceğinin de belirlenmesi önemlidir. Konuşmacının dikkat etmesi gereken üç önemli şey vardır. Bunlar; ritim, sesin volümü ve yüksekliğinin değiştirilmesidir (Aristoteles, 2016). Konuşmacı dili doğru ve etkili kullanabilmelidir. Konuşmanın kendisinden çok, konuşanın ve nasıl konuştuğunun etkili olduğu bilinmektedir. Konuşma metninin hazırlanması yeterli değildir. Konuşma metni ne kadar iyi hazırlanmış olursa olsun dinleyicilerde güven uyandıran ya da güven uyandırabilecek birinin konuşması gerekir. Sözün önemi söyleyen kişiden kaynaklanır. Konuşmacı sesini de doğru ayarlamak durumundadır. Her şey derli toplu yani planlı olmalıdır. Ancak, bu yapmacık olmamalıdır. Aksi durumda dinleyiciler konuşan kişinin samimiyetine inanmayacaklardır. Doğallığın en başarılı strateji olduğu unutulmamalıdır.

Konuşmanın sonuç bölümü dört kısımdan oluşur (Aristoteles, 2016). 1.Dinleyiciler konuşmacının düşmanına dair kötü şeyler düşünmeye başlamalıdır. 2.Önde gelen olgular büyültülmeli ya da küçültülmelidir. 3.Dinleyenlerin duyguları canlandırılmalıdır. 4.Dinleyenlerin bellekleri tazelenmelidir. Bu aşamaların başarılı bir şekilde ortaya konması konuşmacı açısından çok önemlidir.

Konuşan kişinin karakterine dair iyi şeyler düşünülmeye başlanmış ve konuşmacının düşman olarak gösterdiği yere öfke duyulması sağlanmışsa birinci kısım başarıyla tamamlanmıştır. İkinci kısımda ise konuşmacının önemsediği şeyler önemsenmeye, önemsemediği şeyler de küçük ve önemsiz görülmeye başlanmışsa amaca ulaşılmıştır. Üçüncü aşamada ise dinleyiciler coşkulu bir hale getirilmiş ise başarılı olunmuştur. Dördüncü ve son aşamada ise eğer konuşmacı, söylediklerinin üzerinden kısaca bir daha geçmiş ve dinleyenlerin hafızasında söylediklerinin istediği şekilde kalmasını sağlayabildiyse sonuca ulaşmış sayılır.

Aristoteles, hocası Platon ve onun hocası Sokrates gibi retoriği ikna ve kandırmaca olarak görmemekte, nötr bir anlam yüklemekte, retoriği bir meslek, uğraş olarak düşünmektedir. Aristoteles'in retoriği, duyguları harekete geçirmeyi kapsasa da aynı zamanda karakter ve kanıtlarla da ilgilidir. Aristoteles retoriğinde üç ana unsur vardır. Bunlardan ilki karakterdir. Sözün etkisi söyleyen kişinin karakteri ile doğru orantılıdır. Eğer konuşmacı güvenilir ve iyi bir insan olarak görülüyorsa inandırıcılığı da yüksek olur. İkinci ana unsur konuşmacının dinleyenlerin duygularına dokunup dokunamadığı ile ilgilidir. Üçüncü unsur ise konuşulanlara dair kanıtların ortaya konulup konulamaması ile ilgilidir. Bu üç unsuru doğru bir şekilde sağlayan retorik başarılı olarak kabul edilir. Aristoteles retoriği bu üç unsuru ortaya koyması ve ikna sürecini bir meslek olarak görmesinden dolayı önemlidir. Buradan hareketle herhangi bir materyale retorik çözümleme uygulanırken şu üç unsur dikkate alınabilir. 1."Karakter", 2."Duygulara seslenebilme", 3. "Kanıt."

\section{CICCERO VE RETORIKK}

Cicero, Roma tarihinin en önemli hatibi olarak görülmektedir. Cicero, devlet yönetiminde seçkincidir ve aristokratik cumhuriyetin savunucularından olmuştur. Buna rağmen Roma'nın iyiliği ve geleceği için halkın da etkili olduğu karma anayasayı da savunmuştur. Cicero etik ve retorik konuları ile ilgilenmiş ve bu alanlara dair çalışmalar yapmıştır. Cicero'nun retoriğe 
dair görüş belirten filozoflardan (Platon, Aristoteles) farkı kendisinin de bir konuşmacı olmasıdır. Cicero, aynı zamanda bir iletişim pratisyeni, hukukçu ve politikacıdır. Dolayısıyla retoriğin uygulanmasına dair deneyim sahibidir. O dönemde bir Romalı, politikada görev almak istediğinde kamusal alanda ya da mahkemede yani kalabalık önünde konuşma yapmak zorundaydı. Dolayısıyla Roma Cumhuriyeti'nde kamusal konuşma politikanın ayrılmaz bir parçasıdır. Bu durum Yunan kent devletlerindeki demokraside geçerli değildir. Söylev, Roma yönetim sisteminin önemli bir parçasıdır, çünkü kararlar senatodan geçmek durumundadır. Senatoda politikacılar birbirlerini ikna etmek için kamusal konuşmalar yapmışlardır. $\mathrm{Bu}$ nedenle Cicero hem bir retorik teorisyeni hem de bir retorik uygulayıcısıdır (Keskin, 2014).

Cicero'ya göre politika, forumlarda kalabalıklar önünde gerçekleşmeliydi. Forumlarda sergilenecek olan performans ve iletişim iktidar ve erk anlamına gelmekteydi. Ancak, retoriği kullanan kişiler, insanları her şeye yönlendirebileceği için, beraberinde büyük bir sorumluluk da getirmekteydi. Cicero için karizmatik Orator $^{2}$, konuşmanın, iletişimin gücü aracıllı̆̆yla insanlara yön veren kişidir. Bu güç Orator'a toplumsal hayatta güçlü bir etki birakma imkânını sağlar. Orator, retoriğin kendisine sağladığı gücün sorumluluğunu kaldırabilmelidir. Bu nedenle Orator, ahlaki düşünen ve felsefe eğitimi almış ideal bir tip olmalıdır. Cicero, "De oratore" kitabında bu konuları işlemiştir. Eser, Cumhuriyetçi devleti savunma konusunda ögütler vermektedir. Bununla birlikte kitap, kamusal iletişim felsefesinin etiğine de katk1 sağlar. Cumhuriyeti savunmak için konuşan Orator, iyi düşünce, iyi konuşma ve iyi davranış arasında bir bütünlük kurmuş olmalıdır. Cicero'ya göre ideal bir konuşmacının taşıması gereken özellikler; dürüst bir adam olmak, politika ve tarih eğitimi almış olmak, felsefeden anlamak, gelenekleri bilmek ve insan psikolojisinden anlamak, yasalar ve yurttaşlık haklarını bilmektir. Bunlarla birlikte Orator, onurlu bir yaşam sürmelidir. Bu özellikleri sağlayan konuşmacı, iletişimin gücünü kavrayıp kusursuz bir dil geliştirebilir ve ahlaki olgunluğa erişebilir (Keskin, 2014).

Cicero, Platon'un aksine retoriğe dair olumlu düşüncelere sahiptir. Konuşmacının etik değerlerinin onu aldatmacadan koruyacağını ve yalana sapmayacağını düşünür. Cicero'ya göre dürüst bir hatip demokrasi için de ülke için de şanstır. Ancak retorik taktiklerini kullanacak olan hatipler, insanları ikna etme becerisine sahip oldukları için mutlaka bu becerilerle birlikte etik değerlere de sahip olmalıdır. Etik değerler retoriğin aldatmaca olarak kullanılmasının önüne geçmek için vardır. Kalabalıklar önünde gerçekleştirilen dürüst bir konuşma o ülkenin yararına hizmet edecektir. Konuşmacı dürüstlükle birlikte bilgili de olmak durumundadır. Aristoteles için konuşmacının karakteri ikna yolunda çok çok önemlidir. Cicero için de konuşmacının etik değerlere sahip olması aynı öneme sahiptir. Bu durum konuşmanın etkisinden çok sonuçlarının olumlu olması bakımından önemlidir.

Cicero'nun eseri "De oratore" antik dönemin en önemli retorik kitaplarından biri olmuştur. Cicero, eserinde konuşmacının beş klasik görevini ele almıştır. Bu klasik görevler: Malzeme bulma, bölümleme, dilsel anlatım, nimonik, hafıza teknikleri ve sunumdur (Keskin, 2014).

Cicero'nun "De Oratore" çalışması retorik ile ilgilenen araştırmacıların temel referans kaynaklarındandır. Cicero'nun ortaya koyduğu aşamalar; icat etme, düzenleme, üslup, bellek, konuşma tarzıdır. $\mathrm{Bu}$ aşamalar üzerinden retorik çözümleme yapılabilir. "Cicero'nun ileri sürdüğü retorik kanonları, otoritelerce daha önce tespit edilmiş olmasına rağmen; farklı kullanımlarda anlam olanakları sağlayan parçalar halinde ele alınmıştır. Retorik kanonları,

\footnotetext{
${ }^{2}$ Ulus için, ulus adına konuşan sözcüdür.
} 
yeni düşüncelerin ortaya çıkmasına imkân tanıyarak; önerdiği kullanım biçiminin çeşitliliği nedeniyle anlam çözümlemelerinde bir yöntem haline gelebilir” (Durmuş ve Gür, 2017).

\section{YÖNTEM}

Çalışma, Aristoteles'in klasik retorik yaklaşımı üzerine temellendirilmiştir. Tezahüratların analizi aşamasında temel referans Aristoteles'in "Retorik" isimli kitabıdır ve çözümlemede Aristoteles'in alana ilişkin kavramları kullanılmıştır. Antik çağ düşünürleri Platon ve Cicero'nun retorik ile ilgili görüşlerine de kısaca yer verilmiştir.

Çalışmada materyal olarak tezahürat ve sloganların seçilme nedeni; taraftar retoriğini tezahürat ve sloganlar üzerinden analiz etmenin yerinde olacağı düşüncesidir. $\mathrm{Bu}$ amaçla, Duygu Hatipoğlu ve M. Berkay Aydın'ın “Bastır Ankaragücü: kent, kimlik, endüstriyel futbol ve taraftarlık" kitabından (2007) ulaş1lan 100'ün üzerinde tezahürat ve slogan içerisinden, tribün liderlerinin de üzerinde birleştiği, halen kullanılan ve güncelliğini koruyan 20 tezahürat belirlenerek analiz yapılmıştır.

Slogan ve tezahüratlarda; "karakter", "duygulara seslenebilme" ve "kanıt" özelliklerinden hangilerinin ön plana çıktığına bakılmıştır. Aristoteles'in iyi bir konuşmacının taşıması gereken bu özellikleri slogan ve tezahüratlara uygulanmış, örneğin retoriğin unsurlarından "karakter" doğrudan konuşmacının özellikleriyken slogan ve tezahüratlardaki Ankaragücü taraftarının genel özellikleri "karakter” unsuru içerisinde değerlendirilmiştir.

Retorik, ikna etme yollarını kapsamaktadır. Tezahürat ve sloganlar üzerinden taraftar grupları birlikteliklerini pekiştirirler. Dolayısıyla kolektif anlayışının ürünü olan tezahürat ve sloganlarda da amaç iknadır. Hem taraftar grubunun üyelerine hem de dişarıya gönderilen bir mesaj vardır. Bu nedenlerle MKE Ankaragücü Spor Kulübü tezahürat ve sloganlarının retorik analizinin yapılmasının Ankaragücü taraftarlarının duygu ve motivasyonlarını belirlemesi bakımından isabetli olacağı düşünülmüştür.

Retorik çözümlemede amaç iletişimcinin açık ya da çoğu zaman örtük olan anlam yüklemesini iletişim öge ve biçimlerinde aranması olduğu söylenebilir (Sever, 2015). Ankaragücü Spor Kulübü tezahürat ve sloganları tribünde çok sayıda taraftar tarafından söylenmektedir. Ayrıca tezahürat ve sloganlar pankartlarda olduğu gibi sokaklarda duvarlara da yazılmaktadır. Dolayısıyla hem işitsel hem de görsel olarak etkilidirler. Makale kapsamında ise sadece yazı olarak çözümlemeleri yapılacaktır. Ancak makalenin durduğu yer bakımından örtük bir mana aranmayacaktır. Çünkü çözümlenecek materyalin arkasında örtük bir mesaj ya da mana olduğu kabulü ile hareket etmek aynı zamanda ideolojik de bir duruştur. $\mathrm{Bu}$ yöntem daha çok söylem analizi ile ilgilidir. Bunun yerine materyal, Aristoteles'in kavramları ile analiz edilecektir.

\section{TEZAHÜRAT VE SLOGANLARIN RETORIK ANALIZI}

"İyi gününde kötü gününde/hep beraberiz/çünkü biz Ankaragüçlüyüz"

$\mathrm{Bu}$ tezahüratta kulübe ve taraftarlara sadece iyi değil, kötü günde de birlikte olma vaadi verilmiştir. Tezahüratta, aidiyet, "biz" olma ve birlikte hareket etme vaadi vardır. "Ankaragüçlüyüz" ifadesiyle aidiyet ile övünülmüştür. Kötü günde birlikte olma erdemi "biz" vaadi ile ilgilidir. Ayrıca başarısızlığın birlikte sırtlanacak olması aidiyetten alınan güçle ilgilidir. "Beraberiz" ifadesinden de birlikte hareket etmekten duyulan keyif ve gurur anlaşılmaktadır. "Biz", aidiyet ve birlikte hareket etme duyguları ön plandadır. Bu nedenle retorik unsurlardan "duygulara seslenebilme" vardır diyebiliriz. 
“Ankaragüçlü olunmaz/Ankaragüçlü doğulur/Ankaragüçlü olmayanlar/İstanbul çocuğudur” $\mathrm{Bu}$ tezahüratta aidiyet ve "biz" vurgusu ağır basmaktadır. "Ankaragüçlü” olma vurgusu aidiyete karşılık gelmektedir. Ankaragüçlü olmayanlara gönderme yapılarak, İstanbul ve Anadolu kıyaslaması ve yarıştırması söz konusu edilmiştir. Ankaragücü taraftarı için İstanbullu olmak kötü bir özelliktir. İstanbullu olmama olumlu özelliği "biz" ile ilgilidir. Çünkü "biz" tüm olumlu özellikleri taşır ve olumsuzlukları dışarıda bırakır. Retoriğin "duygulara seslenebilme" özelliği ile örtüşen bir tezahürattır. "İstanbullu" olmama "Ankaralı", "Anadolulu" olma duygusuna seslenilmiştir. Ankaragücü taraftarının Ankaralı ve Anadolulu olma özelliği, karakteri vurgulanmıştır. Aristoteles retoriğinin "karakter" ve “duygulara seslenebilme” özelliklerini taşıyan bir tezahürattır.

"Her zaman her yere gider/ ne yağmur ne çamur dinler/ severse gönülden sever/ bu alemde Ankaragüçlüler"

Tezahüratta Ankaragücü'ne duyulan sevgi ve destek ön plandadır. "Duygulara seslenebilme" retorik unsuru vardır. Ankaragücü taraftarının her koşulda her zaman takımına destek olduğu karakteristik bir özellik olarak vurgulanmıştır. Retorik unsurlardan "karakter" ögesi dikkat çekmektedir. Her zaman her koşulda birlikte hareket edildiği vurgusu vardır. Olumsuz durumlarda dahi birlikte hareket etmek, birlikteliği bozmamak işlevseldir. Olumsuzluk ile hep birlikte başa çıkılır. Bireysel olarak bir güçlüğü, başarısızlığı gidermek zordur ancak birlikte hareket edilerek bu olumsuz durum savuşturulur.

"Gururluyuz güçlüyüz Ankaragüçlüyüz"

$\mathrm{Bu}$ sloganda Ankaragücü taraftarına olumlu özellikler yüklendiği görülmektedir. Sloganda vaat "gururlu" ve "güçlü" olmaktır. "Gurur" ve "güç" Ankaragücü taraftarlığ 1 ile özdeşleştirilmiştir. Slogan aidiyet ihtiyacı ve "biz" duygusu ile örtüşmektedir. Olumlu özellikler gruba özgü kabul edilir. "Ankaragüçlüyüz” ifadesinde de aidiyet açıkça belirtilmiş ve bu aidiyet üzerinden kimlik tanımı yapılmıştır. Retorik unsurlardan "duygulara seslenebilme" ve "karakter" ögeleri dikkat çekmektedir. Gururlu ve güçlü olmak Ankaragücü taraftarının genelinin karakteristik bir özelliği olarak tezahüratta vurgulanmıştır.

"Saldırın saldırın saldırın, bu taraftar için saldırın"

Tezahüratta mücadele beklentisi dile getirilmiştir. Taraftarlar mücadeleyi "öteki”" olana karşı verir. Bu mücadele "biz" ile ilgilidir. Retorik unsurlardan da "duygulara seslenebilme" ön plandadır.

"Saldırın durmadan/ bu taraftar arkanızda her zaman/ başkente rahat yok/ Ankara'da... koymadan"

Tezahüratta mücadele beklentisi ile birlikte her zaman destek vaadi görülmektedir. Mücadele beklentisi "biz" duygusu ile ilgilidir. Destek vaadi ise aidiyet ihtiyacına karşılık gelmektedir. Tezahürat argo bir söylemle tamamlanmaktadır. Retorik unsurlardan da "duygulara seslenebilme" vardır.

"Çık bakalım çık bakalım/ dışarıya çık bakalım/ emaneti gör, sallamayı gör/ delikanlı kim bakalım"

Tezahüratta "öteki" olana meydan okuma ve şiddet vardır. Bu nedenle tezahürat "biz" duygusuna karşılık gelmektedir. "Biz" duygusu taraftarları motive eden ve bir arada tutan başlıca motivasyonlardandır. Retorik unsurlardan da "duygulara seslenebilme" vardır. 
“Ooo bıraktık işi gücü/ bıraktık işi gücü/ bıraktık işi gücü/ saldır Ankaragücü”

Tezahüratta tekrardan yararlanılmıştır. Ankaragücü'nün her şeyden üstte tutulduğu görülmektedir. Tezahürat aidiyet ihtiyacı ile ilgilidir. Retorik unsurlardan da "duygulara seslenebilme" unsuru ön plandadır.

"Bastır Ankaragücü/haydi bastır..."

"Bastır" kelimesinden de anlaşıldığg gibi burada mücadele vurgusu vardır. Mücadele vurgusu motivasyonlardan biz ile örtüşmektedir. Çünkü biz motivasyonu mücadeleyi ve şiddeti de içeren aktif bir motivasyondur. Ankaragücü taraftarı bu tezahüratında mücadele beklentisini ve hırsını ortaya koymuştur. Retorik unsurlardan "duygulara seslenebilme" vardır.

"Bitanem söyle başkent/ ne istersen iste benden/ istersen donatalım dört bir yanı bayraklarla/istersen çınlatalım dört bir yanı şarkılarla/ istersen gidelim deplasmanlara konvoylarla"

Tezahüratta takıma destek vurgusu dikkat çekerken, retorik unsurlardan "duygulara seslenebilme" ön plandadır. Taraftar bayraklarla şarkılarla takımına destek olarak birlikte hareket etmektedir. Ayrıca şarkılar, bayraklar ve birlikte hareket etmek taraftarları "kardeş" kılmaktadır. Farklılık değil, benzerlik üzerinde durulurken, tezahüratta kardeşlik vurgusunu ön plana çıkartılmaktadır.

"Ankaragüclüler ananızı s...ecekler"

Tezahüratta "öteki" olarak görülene küfür, hakaret ve meydan okuma vardır. Tezahüratta retorik unsurlardan "duygulara seslenebilme" vardır. Tezahürat "biz" duygusuna karşılık gelmektedir. Tezahüratta aynı zamanda karşı tarafa küfürle öfkesini yansıtma vardır. Öfkeden doğan bir kardeşlik ve dayanışma ruhu hem kitleyi bir arada tutmakta hem de düşmana karş1 eyleme geçirmektedir.

"Bağırmayan taraftar s...irsin gitsin"

Tribünlerde önemli olan takıma verilen destektir. Bunun dışında hiçbir başarının, hiçbir farklılığın önemi yoktur. Grup, taraftarı kulübe verdiği destek üzerinden değerlendirir. Bu nedenle tezahürat hem aidiyet hem de birliktelik duygusu ile örtüşmektedir. Retorik unsurlardan da "duygulara seslenebilme" vardır. Normlara uymayan davranışta bulunan taraftarları da dışlayan bir anlayış dikkati çekmektedir.

"Haydi haydi haydi Allah aşkına/ İstanbul'un i...leri dönsün şaşkına"

Tezahüratta "öteki" olarak kabul edilen İstanbul takımlarına argo ifadelerle sataşma vardır. "Ötekinin" varlı̆ğ "biz" ile ilgilidir. "Ötekinin" varlığı üzerinden "biz" tanımı yapılır. Tezahürat "biz" duygusu ile ilgilidir. Sataşma ve meydan okuma duygularla ilgilidir. Retorik unsurlardan "duygulara seslenebilme" öne çıkmaktadır. Biz duygusu ortaya koyduğu davranışlarla retorik unsurlardan" karakter" ögesini de desteklemektedir.

"Ne Beşiktaş ne Cimbom ne de Kanarya/ en büyük sensin Ankara/ ölümüne ölümüne ölümüne şanlı başkent"

Tezahüratta Ankaragücü taraftarına en büyük olma vaadi sunulmaktadır. Vaatler duygulara seslendiği için retorik unsurlardan "duygulara seslenebilme" kullanılmıştır diyebiliriz. "Öteki" olarak görülenlere meydan okuma olduğu için de biz duygusunun ön planda olduğu bir tezahürattır. "Başkent" vurgusundan dolayı aidiyet vurgulanmıştır. 
“Ankaragücüm (büyük başkent) sen çok yaşa canım feda olsun sana/ hiçbir şeye değişilmez senin sevgin şu dünyada"

Tezahüratta kulübe duyulan sevgi ön plandadır. Sevgi duygusuna seslenen bir tezahürattır. Bu nedenle retorik unsurlardan "duygulara seslenebilme" vardır. Aidiyet ön planda olduğu için tezahürat aidiyet ihtiyacı ve duygusuna da seslenmektedir.

"Hükümet düşer/ enflasyon düşer/ Ankaragücü babayı düşer"

Tezahüratta aidiyete duyulan güven ön plandadır. Mesaj, güven olduğu için retorik unsurlardan "duygulara seslenebilme" görülmektedir. Güven duygusu ile birlikte aidiyet duygusuna da seslenen bir tezahürattır.

"İşte coşku işte tutku burası gecekondu"

$\mathrm{Bu}$ sloganda retorik unsurlardan "duygulara seslenebilme" vardır. Coşku ve tutku ön plana çıkartılmış ve gecekondu taraftar topluluğu ile özdeşleştirilmiştir. Gecekondu taraftar topluluğuna duyulan kuvvetli inanç ve bağlılık sloganda coşku ve tutku duygularına seslenilerek ifade edilmiştir. Gecekondu vurgusu yapılmıştır. Aidiyet duygusuna karşılık gelen, ayrıca taraftarlara coşku ve tutku vaat eden bir slogandır.

"Söyle seni sevmedik mi/ sana gönül vermedik mi/ yağmurlarda çamurlarda/ her maçına gelmedik mi/ gelmedik mi başkent gelmedik mi/ gün geldi sahipsiz kaldık/ tribünlerde tartaklandık/ her cefayı çektik ama/ seni yalnız bırakmadık/ bırakmadık başkent bırakmadık/ hepimiz aynı yoldayız/ bir bütünüz kopamayız/ and içtik senin yoluna/ ölene dek bırakmayız/ bırakmayız başkent bırakmayı"

Tezahüratta sevgi vurgusu ve retorik unsurlardan "duygulara seslenebilme" vardır. Taraftar sevgisine kanıt olarak geçmişi kanıt göstermekte, çekilen sıkıntılara rağmen her zaman takımın yanında olduğuna vurgu yapmaktadır. Aynı yolda ve bir bütün olunduğu ifadeleri de kardeşlik duygusuna karşılık gelmektedir. Farklılık utanılacak bir şeydir, önemli olan bir bütün olabilmektir. Ölene kadar birlikte olmak ve kopmamak vurguları da dikkat çekmektedir. Çünkü taraftar grubunun dışına çıkmak ya da çıkartılmak artık var olamamak demektir. Bu durumda kişi "kardeşlerinden” ve aidiyetinden kopartılmış olur.

"İçerde dışarda bütün maçlarda/ bu büyük taraftar senin yanında/ övünmek gibi olmasın ama/ sapına kadar biz Ankaragüçlüyüz/ Ankaragüçlüyüz Ankaragüçlüyüz/ sapına kadar biz Ankaragüçlüyüz"

Tezahüratta aidiyet ile gelen kimlikle yani Ankaragüçlü olmakla övünülmektedir. Tezahüratta argo da içeren tekrar dikkat çekmekte, tezahüratın akılda kalıcılığını sağlamaktadır. Tezahüratta Ankaragüçlü olmanın "büyüklük” getirdiği vaadi vardır. Aidiyetin ön plana çıkarıldığı bir tezahürattır. Tezahüratta retorik unsurlardan "duygulara seslenebilme" vardır.

“T1k tık tık/ kim o? / öcüüüüü/ Ankaragücüüü Ankaragücüü”

Tezahüratta tekrardan yararlanılmıştır. Ankaragücü vurgusu vardır. Bu nedenle aidiyet duygusuna seslenen bir tezahürattır. Rakiplerin Ankaragücü'nden korktuğu göndermesi yapılmakta, bu nedenle tezahürat "biz" duygusuna da karşılık gelmektedir. Retorik unsurlardan ise "duygulara seslenebilme" ön plandadır.

\section{TARTIŞMA VE SONUÇ}

MKE Ankaragücü, işçiler ve işçi temsilcileri tarafından kurulan, Kurtuluş Savaşı ile Ankara'ya taşınan, sınırlı sportif başarılarına karşın, tarihi boyunca hep kitlesel bir desteğe sahip olan özgün bir kulüptür (Aydın, 2018). Ankaragücü, İstanbul takımlarına göre sınırlı 
sayıda taraftara sahip olmasına rağmen takımlarına güçlü bir bağlılık duyan aktif bir kitleye sahiptir. Ankaragücü taraftar grubu, takımlarının ligden düştüğü dönemlerde bile deplasman dahil her maçını takip etmiştir. Taraftarlık onların yaşam biçimi haline gelirken, geliştirdikleri taraftar kimlikleri yaşamlarının merkezinde yer almaktadır (Hacısoftaoğlu ve ark., 2012).

Ankara'da farklı bir taraftar profiline sahip Ankaragücü'nün slogan ve tezahüratları incelendiğinde; Aristoteles'in retorik türlerinden törensel gösteri söylevine yakın olduğu görülmektedir. Slogan ve tezahüratlarda Ankaragücü erdem ve iyiliğin kaynağı olarak sunulurken, bütün kusur ve kötülükler "ötekine” yani rakibe yüklenmektedir. Tribün liderleri bunu yaparken taraftar grubunun değer yargıları ve yaşama karşı duruşunu bilerek hareket etmekte, grubun karakteriyle örtüşen argo ve hakaret içeren bir dil kullanmaktan da çekinmemektedir. Bu dil taraftarı bir arada tutmanın yanı sıra retoriğin en önemli unsuru olan ikna için kullanılmaktadır. Aksi taktirde taraftarı ikna etmek ve biz duygusunu yerleştirmek oldukça zorlaşmaktadır.

Aristoteles retoriğinde ethos, karakter, pathos, duygulara dokunabilme, seslenebilme, logos ise belge, mantık olarak karşımıza çıkmaktadır. Ethos, pathos ve logos kavramlaştırmalarının taraftarı ikna sürecinde ve sloganlarda kullanımına baktığımızda ise logos (belge ve mantık) dışındaki unsurların etkin bir şekilde kullanıldı̆̆ı görülmektedir.

Slogan ve tezahüratlara yakından bakıldığında biz anlayışını netleştirmek için öfke duygusunun harekete geçirilmeye çalışıldığ da dikkat çekmektedir. Sloganlarda rakibe yöneltilen öfke ve öç alma duygusundan, taraftarı diri tutmak ve motivasyonunu artırmak için faydalanılmaktadır. Öfke ve öç alma isteği taraftarı eyleme geçmeye yönlendirmektedir. "Öteki” olana duyulan öfke de doğal olarak "biz" duygusunu kuvvetlendirmektedir.

Ankaragücü slogan ve tezahüratlarına retorik çözümleme uygulandığında, slogan ve tezahüratlarda tekrardan yararlanıldığı görülmüştür. Slogan ve tezahüratlarda retorik unsurlardan en çok görülen "duygulara seslenebilme" unsurudur. Slogan ve tezahüratlarda "karakter" unsurundan da yararlanıldığg görülmektedir.

Çözümlemede retorik unsurlardan "karakter" Ankaragücü taraftarına dair genel özellikler olarak ele alınmıştır. Retoriğin üç temel unsurundan ilk ikisi slogan ve tezahüratlarda mevcuttur. Ancak üçüncü unsur olan "belgeye dayanma" slogan ve tezahüratlarda karşımıza çıkmamaktadır. Taraftar retoriğine bakıldığı için bu şaşırtıcı bir durum değildir. Duygusallık taraftarlığın doğasında olduğundan hemen hemen tüm slogan ve tezahüratlarda retorik unsurlardan "duygulara seslenebilme" vardır ve diğer iki retorik unsura kıyasla daha ağır basmaktadır.

Tezahürat ve sloganlarda en çok görülen duygu ve ihtiyaç, aidiyettir. Aidiyetle birlikte "biz" duygusu ve anlayışı da ortaya çıkmaktadır. Slogan ve tezahüratlarda "biz” övülürken, "öteki” olarak görülen rakip takım taraftarları olumsuz özellikler yüklenerek aşağıya çekilmeye çalışılmaktadır. Ankaragücü slogan ve tezahüratları askeri marşlar gibi "dosta" güven "düşmana" korku vaat etmektedir. Bütün tribün bu tezahüratları söylediğinde retoriğin işitsel etkisi de artmaktadır.

\section{KAYNAKLAR}

Altınörs, A. (2011) Platon ile Aristoteles'in retorik anlayışlarının karşılaştırılması, Ekev Akademi Dergisi, 15(49), 81-92. 
Aristoteles.(2016). Retorik. (Çev. Mehmet H. Doğan). İstanbul: Yapı Kredi Yayınları.

Aydın, M., B. (2018). Ankara'nın sosyo-kültürel bir değeri olarak MKE Ankaragücü: Taraftarların gözünden kent ve kulüp. Ankara Araştırmaları Dergisi. 6(1), 1-22.

Beer, M.(2001). Insanı ikna etme ve kazanma. (Çev. Ali Dülger). Eskişehir: Bilim Teknik Yayınevi.

Delice, E. (2007). Aristoteles felsefesinde tasımsal tanıt ve diyalektik ilişkisi. Ankara Üniversitesi Sosyal Bilimler Enstitüsü Felsefe Anabilim Dalı, Yayımlanmamış Doktora Tezi, Ankara.

Durmuş, S., Gür, Ş. Ö. (2016). Mimarlığın metinsel temsilinde retorik inşa: Usûl-İ Mi’Mârî-İ Osmanî. ODTÜ Mimarlık Fakültesi Dergisi, 34(1), 107-131.

Hacısoftaoğlu, İ., Akcan, F., Bulgu, N. (2012). Hayali cemaatler olarak taraftar toplulukları: Ankaragücü taraftar grupları örneği. Hacettepe Spor Bilimleri Dergisi, 23(4), 159-176.

Hatipoğlu D., Aydın M. (2007). Bastır Ankaragücü: Kent, kimlik, endüstriyel, futbol ve taraftarlık. Ankara: Epos Yayınları.

Keskin, F. (2010). Politik profesyoneller ve uzmanlar. Ankara: De Ki Basım Yayın.

Keskin, F. (2014). Politik iletişim sözlüğ̈̈̈. Ankara: İmge Kitabevi.

Platon. (2005). Şölen. (Çev. Cüneyt Çetinkaya). İstanbul: Bordo Siyah Klasik Yayınları.

Platon. (2010). Sokrates 'in savunması. (Çev. Özgü Çelik). İstanbul: Say Yayınları.

Platon. (2017). Gorgias. (Çev. Mehmet Rifat- Sema Rifat). İstanbul: Türkiye İş Bankası Kültür Yayınları.

Pratkanis A., Aronson E. (2008). Propaganda Çă̆ı. (Çev. Nagihan Haliloğlu). İstanbul: Paradigma Yayıncılık.

Sever, S. (2015). Retorik analiz ve reklamlarda kullanımı. Iletişim araştırmalarında yöntemler. Besim Yıldırım (der) içinde. Konya: Literatürk Academia. 